\title{
Merencanakan Pemecahan Masalah Kontekstual: Berpandu pada Rumus atau Konteks?
}

\author{
Suki Isffi Ani ${ }^{1}$, Abdul Haris Rosyidi ${ }^{2}$ \\ ${ }^{1,2}$ Program Studi Pendidikan Matematika, Universitas Negeri Surabaya \\ E-mail: suki.18006@mhs.unesa.ac.id ${ }^{1}$ abdulharis@unesa.ac.id ${ }^{2}$
}

\begin{abstract}
Abstrak
Penelitian ini bertujuan untuk menganalisis proses perencanaan penyelesaian masalah konstektual. Subjek penelitian terdiri dari tiga siswa kelas IX SMP. Penelitian yang digunakan adalah penelitian kualitatif dengan pendekatan deskriptif. Instrumen yang digunakan adalah wawancara berbasis tugas. Data dianalisis sesuai dengan indikator dari pemecahan masalah pada tahap merencanakan yaitu mengidentifikasi informasi, memilih pengetahuan lama yang dapat digunakan dalam penyelesaian masalah, menyebutkan teorema yang terkait dengan masalah, membuat rencana. Pada hasil penelitian diperoleh bahwa siswa pertama mampu mengidentifikasi informasi yang diperlukan namun siswa tidak menyampaikan secara tertulis. Siswa pertama menyelesaikan soal menggunakan rumus volume, namun siswa mengalami kesalahan konsep saat ditengah penyelesaian. Siswa kedua mampu mengidentifikasi dan menuliskan informasi yang diperlukan, Siswa kedua menggunakan rumus matematis dan perkiraan untuk menentukan banyak kertas kado yang dibutuhkan. Siswa ketiga mampu memahami manakah informasi yang dapat digunakan dan informasi yang berlebih. Pada mulanya siswa ketiga menggunakan rumus untuk menyelesaikan persoalan, namun ditengah penyelesaian siswa merubah perencanaan dengan menerapkan aplikasi kehidupan nyata/konteks. Berdasarkan hasil penelitian yang dilakukan bahwa dua siswa dari tiga siswa saat menyelesaikan permasalahan tidak memperhatikan konteks.
\end{abstract}

Kata Kunci: bangun ruang, pemecahan masalah, perencanaan

\section{Planning Contextual Problem Solving: Based on Formula or Context?}

\begin{abstract}
This study aims to analyze the planning process for solving contextual problems. The research subjects consisted of three students of class IX SMP. The research used is a qualitative research with a descriptive approach. The instrument used is a task-based interview. The data is analyzed according to the indicators of problem solving at the planning stage, namely identifying information, selecting old knowledge that can be used in problem solving, mentioning theorems related to the problem, making plans. The results showed that the first student was able to identify the information needed but the student did not submit it in writing. The first student solved the problem using the volume formula, but the student experienced a conceptual error in the middle of completion. The second student is able to identify and write down the required information, the second student uses mathematical formulas and estimates to determine the amount of wrapping paper needed. The third student is able to understand which information can be used and which information is redundant. At first the third student used the formula to solve the problem, but in the middle of the completion the student changed the plan by applying real life/context applications. Based on the results of research conducted that two students out of three students when solving problems did not pay attention to the context.
\end{abstract}

Keywords: devise a plan, geometry, problem solving

\section{PENDAHULUAN}

Pemecahan masalah merupakan salah satu bagian penting dari belajar matematika. Pemecahan masalah merupakan salah satu dari standar kemampuan yang harus dimiliki oleh semua siswa. Memecahkan masalah merupakan hal yang sering dilakukan manusia, karena dikehidupan sering sekali dihadapkan dengan masalah. Keterampilan serta kemampuan berpikir yang didapat ketika seseorang 
memecahkan masalah diyakini dapat ditransfer atau digunakan orang tersebut ketika menghadapi masalah dalam kehidupan sehari-hari. Namun berdasarkan hasil penelitian Kaliky, Nurlaelah, \& Jupri (2019) diperoleh bahwa kemampuan siswa dalam memecahkan masalah masih sangat rendah dan jauh di bawah rata-rata.

Penelitian yang dilakukan Dindyal, Tay, Toh, Leong, \& Quek (2012) dan Simpol, Shahrill, Li, \& Prahmana (2017) menunjukkan bahwa penggunaan strategi pemecahan masalah Polya dapat meningkatkan kemampuan pemecahan masalah siswa. Menurut hasil penelitian yang dilakukan Utami (2013), strategi pemecahan masalah Polya efektif dalam meningkatkan kreatifitas siswa. Pemecahan masalah tersebut terdiri dari empat langkah yaitu, memahami masalah, merencanakan penyelesaian, melaksanakan perencanaan, memeriksa kembali (Polya, 1945).

Salah satu langkah dalam pemecahan masalah adalah merencanakan penyelesaian. Perencanaan memiliki peran yang sangat penting dalam penyelesaian masalah. Salah satu peran merencanakan penyelesaian masalah yaitu siswa dapat menentukan definisi, konsep bahkan teorema yang dapat digunakan dalam menyelesaikan suatu masalah hal tersebut sesuai dengan penelitian yang telah dilakukan oleh Nadhifa, Maimunah, \& Roza (2019). Siswa yang dapat membaca dan memahami permasalahan akan mengingat bahwa dia pernah menyelesaikan masalah yang hampir sama sehingga siswa dapat menentukan penyelesaian yang dapat digunakan dalam menyelesaikan permasalahan yang baru saja dijumpai.

Kebanyakan siswa sering mengabaikan tahap perencanaan (Arfiana \& Wijaya, 2018). Hal ini menunjukkan bahwa kemampuan perencanaan siswa dalam pemecahan masalah masih sangat kurang. Sering juga dijumpai siswa yang sudah bisa merencanakan penyelesaian masalah namun tidak bisa menyampaikan secara tertulis (Saputri, 2019). Hasil dari penelitian sebelumnya yang dilakukan oleh Puadi (2017) menyatakan bahwa keterampilan siswa dalam memilih proses atau strategi masih sangat rendah. Maka dari itu perlu dilatihnya perencanaan karena dalam perencanaan siswa akan terampil dalam memilih strategi yang tepat saat melakukan proses perencanaan, hal tersebut juga dikarenakan banyak guru yang tidak membiasakan menanyakan tentang perencanaan kepada siswa (Polya, 1985).

Salah satu jenis masalah yang sering ditemui dan penting untuk dipelajari yaitu mengenai masalah kontekstual. Siswa salah dalam menyelesaikan permasalahan karena siswa tidak melihat hubungan persoalan dengan konteks kehidupan sehari-hari. Dengan menggunakan masalah kontekstual siswa dapat dengan mudah melewati proses matematisasi dan mengembangkannya dalam dirinya sendiri. Sesuai dengan hasil penelitian dari Anggo (2011) bahwa pembelajaran matematika berbasis kontekstual mampu meningkatkan kemampuan metakognisi siswa. Dengan demikian siswa akan lebih mudah memahami konsep matematika karena dalam pembelajaran siswa mempelajari konsep matematika melalui hal yang nyata bukan hal yang abstrak.

Merencanakan penyelesaian merupakan salah satu tahap yang digunakan sebagai upaya melatih kemampuan pemecahan masalah. Perencanaan penyelesaian merupakan tahap yang termasuk ke dalam kesalahan dengan kategori yang cukup tinggi yang sering dilakukan oleh siswa (Rofi'ah, Ansori, \& Mawaddah, 2019). Pada tahap merencanakan ini siswa harus dapat menemukan hubungan antara data yang diketahui dengan data yang ditanyakan. Pada tahap ini juga berkaitan dengan strategi yang akan digunakan oleh siswa

Materi bangun ruang merupakan materi yang berkaitan dengan konteks kehidupan sehari-hari namun masih dirasa sulit oleh kebanyakan siswa. Hal ini ditunjukkan dengan rendahnya kemampuan pemecahan masalah siswa dalam materi bangun ruang (Lestari, Rohaeti, \& Purwasih, 2018; Putra, Thahiram, Ganiati, \& Nuryana, 2018; Rio \& Pujiastuti, 2020). Siswa tidak menyadari bahwa materi bangun ruang sangat berkaitan dengan konteks nyata sehingga siswa hanya berpacu pada hasil perhitungan yang ditemukan (Lestari et al., 2018; Rio \& Pujiastuti, 2020).

Penelitian ini membahas perencanaan penyelesaian masalah. Proses perencanaan siswa terdiri atas 4 tahap, yaitu siswa mampu mengidentifikasi informasi yang terdapat pada soal, siswa mampu mengetahui pengetahuan lama yang dapat digunakan dalam penyelesaian masalah yang saat ini dijumpai, siswa mampu menyebutkan teorema atau definisi yang terkait, dan yang terakhir siswa mampu membuat rencana untuk menyelesaikan masalah yang dihadapi. 


\section{METODE}

Jenis penelitian yang digunakan adalah penelitian kualitatif dengan pendekatan deskriptif. Subjek dalam penelitian ini terdiri dari 3 siswa kelas IX SMPN di salah satu kota Magetan. Penentuan subjek dengan purposive sampling, dimana subjek penelitian yang dipilih telah mempelajari materi bangun ruang. Penelitian ini dilakukan pada 14 Maret 2021.

Instrumen penelitian berupa wawancara berbasis tugas. Tugas yang dimaksud adalah tes pemecahan masalah kontekstual pada materi luas dan volume balok. Bentuk soal yang digunakan bentuk soal uraian, soal tersebut telah divalidasi dari segi isi dan bahasa. Berikut tes pemecahan masalah:

"Ani ingin membungkus kado dalam bentuk balok. Kardus tersebut akan diisikan 12 coklat batangan dan 1 album. Ukuran 1 kotak coklat $15 \mathrm{~cm} \times 10 \mathrm{~cm} \times 5 \mathrm{~cm}$ dengan harga Rp7000,00 dan ukuran album $30 \mathrm{~cm} \times 20 \mathrm{~cm} \times 10 \mathrm{~cm}$. Kardus tersebut akan diselimuti dengan kertas kado, jika di toko hanya tersisa kertas kado yang berukuran $40 \mathrm{~cm} \times 45 \mathrm{~cm}$, berapa banyak kertas kado yang dibutuhkan?"

a. Tuliskan rencanamu untuk menyelesaikan soal tersebut!

b. Mengapa kamu merencanakan seperti itu?

c. Andaikan perencanaamu gagal, tuliskan rencana lain!

Analisis data penelitian ini dilakukan dengan cara menganalisis lembar jawaban siswa dan dianalisis pada aspek perencanaannya. Hasil analisis lembar jawaban akan dikombinasikan dengan wawancara. Teknik wawancara dilakukan berdasarkan indikator yang telah disusun sebelumnya. Langkah yang digunakan setelah data terkumpul kemudian di analisis berdasarkan jawaban tes dan hasil wawancara yang berpedoman pada indikator merencakan pemecahan masalah. Indikator yang digunakan untuk mengukur kemampuan pemecahan masalah siswa pada tahap merencanakan dapat dilihat pada Tabel 1.

Tabel 1. Indikator Pemecahan Masalah tahap Merencanakan

\begin{tabular}{clc}
\hline & \multicolumn{1}{c}{ Indikator } & Kode \\
\hline 1.1 & Mengidentifikasi informasi yang terdapat pada soal & MI \\
1.2 & Memilih pengetahuan lama untuk dikaitkan pada permasalahan & MP \\
1.3 & Menyebutkan teorema atau definisi terkait masalah & MT \\
1.4 & Membuat rencana & MR \\
\hline
\end{tabular}

\section{HASIL DAN PEMBAHASAN}

Berikut penjabaran hasil tes dari ketiga siswa mengenai tahap merencanakan yang terkait dengan materi bangun ruang, berdasarkan hasil tes siswa dan hasil wawancara siswa terhadap indikator yang digunakan dalam penelitian ini.

\section{Siswa 1 (A)}

Siswa 1 tidak menuliskan informasi yang tertera dan informasi yang tidak ada pada soal namun siswa sudah memahami informasi apa yang dibutuhkan dan yang dicari. Berikut hasil jawaban siswa, dapat dilihat pada Gambar 1. 


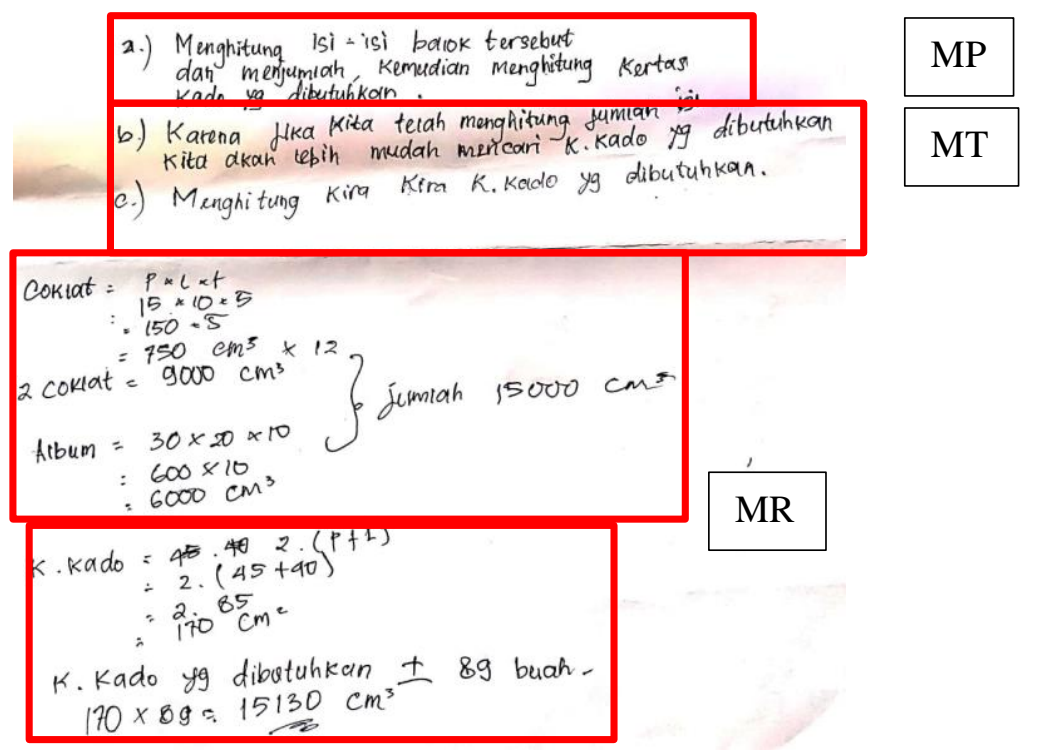

Gambar 1. Jawaban Siswa 1 (A)

\section{Mengidentifikasi Informasi}

$\mathrm{P} \quad$ : apa informasi yang terdapat pada soal?

A11 : banyak kertas yang ingin digunakan, dan diketahui ukuran coklat, album, kertas kado

P : kenapa tidak menuliskan pada lembar jawaban?

A12 : saya tidak terbiasa menuliskannya karena menurut saya terlalu lama.

Dari hasil pekerjaan subjek pertama pada Gambar 1, subjek tidak menuliskan informasi yang diperlukan untuk menyelesaikan masalah. Berdasarkan hasil wawancara pada A11 siswa sudah bisa memahami informasi yang dibutuhkan, informasi yang diperlukan dan juga informasi yang tidak perlu dipakai. Sesuai dengan A12, siswa memang tidak terbiasa untuk menuliskan informasi sebelum mengerjakan. Sehingga dapat dilihat pada lembar jawaban, bahwa siswa langsung mengerjakan tanpa menuliskan informasi yang terdapat pada soal.

\section{Mengaitkan dengan pengetahuan lama}

$\mathrm{P} \quad$ : apa kamu pernah menjumpai masalah yang serupa? atau mungkin dalam bentuk yang berbeda?

A21 : kalau sama sepertinya belum, namun ada yang mirip yaitu ada sebuah bangun yang tidak diketahui ukurannya kemudian disuruh mencari luas dari bangun tersebut untuk ditutupi sesuatu.

Dari hasil pekerjaan subjek pertama pada Gambar 1 kode MP, subjek mampu mengaitkan dengan pengetahuan lama yaitu dengan menulis rumus yang pernah ia pelajari sebelumnya, sesuai dengan A21.

\section{Menyebutkan Teorema atau definisi yang terkait}

$\mathrm{P} \quad$ : sehingga apakah menurut kamu penyelesaian masalah yang pernah kamu jumpai bisa diterapkan?

A31 : iya bisa, sehingga saya menyelesaikannya dengan menghitung dulu volume box tersebut. Setelah itu mencari keliling dari kertas kadonya

$\mathrm{P} \quad$ : kenapa kamu mencari keliling?

A32 : karena kertas kado mengelilingi kardus sehingga saya menggunakan rumus keliling

Dari hasil pekerjaan subjek pertama pada Gambar 1 kode MT, bahwa siswa sudah dapat menyebutkan teorema yang terkait yaitu dengan menuliskan rumus yang dapat ia gunakan. Terlihat dari hasil wawancara pada A31 bahwa siswa menggunakan rumus yang pernah ia gunakan sebelumnya dan menerapkan pada soal ini. Pada A32 siswa berpikir bahwa selain menggunakan volume dia juga menambahkan rumus yang menurutnya cocok untuk digunakan dalam masalah ini. Pada tahap ini terjadi kesalahan dikarenakan siswa menambahkan rumus tanpa berpikir ulang bahwa masalah pada soal ini adalah bangun ruang, akan tetapi siswa menggunakan rumus yang ada pada bangun datar. 


\section{Membuat rencana}

$\mathrm{P} \quad$ : lalu langkah apa yang kamu lakukan dari informasi yang telah kamu dapat?

A41 : saya bandingkan antara 2 informasi itu dan setelah itu dapat diketahui membutuhkan berapa kertas kado

$\mathrm{P} \quad$ : lalu bagaimana caranya bisa mendapatkan banyak 89 ?

A42 : saya menggunakan kira-kira

$\mathrm{P} \quad$ : kira-kira seperti apa?

A43 : saya cari kelilingnya agar hampir mirip dengan volumenya jadi harus dikali berapa, sehingga pengali itu merupakan banyak kadonya.

Dari hasil pekerjaan subjek pertama pada Gambar 1 kode MR, subjek mencari volume masingmasing isi kardus lalu menjumlahkan semuanya untuk mendapatkan volume kardus. Kemudian siswa juga mencari keliling dari kardus, berdasarkan A41. Hasil pekerjaan siswa yang ada pada gambar siswa menuliskan bahwa jumlah kertas kado yang digunakan adalah 89. Menurut hasil wawancara A42 dan A43 siswa hanya mengira-ngira untuk mendapatkan hasil tersebut. Pada tahap membuat rencana ini siswa juga mengalami kesalahan dikarenakan pada tahap sebelumnya siswa salah dalam memilih rumus, akhirnya siswa memaksakan hasil yang ia peroleh.

\section{Siswa $2(\mathbf{R})$}

Siswa sudah dapat menuliskan informasi yang didapat dari soal dan informasi yang belum diketahui, hal ini dapat dilihat dari hasil jawaban siswa. Berikut hasil jawaban siswa dapat dilihat pada Gambar 2 dan Gambar 3.

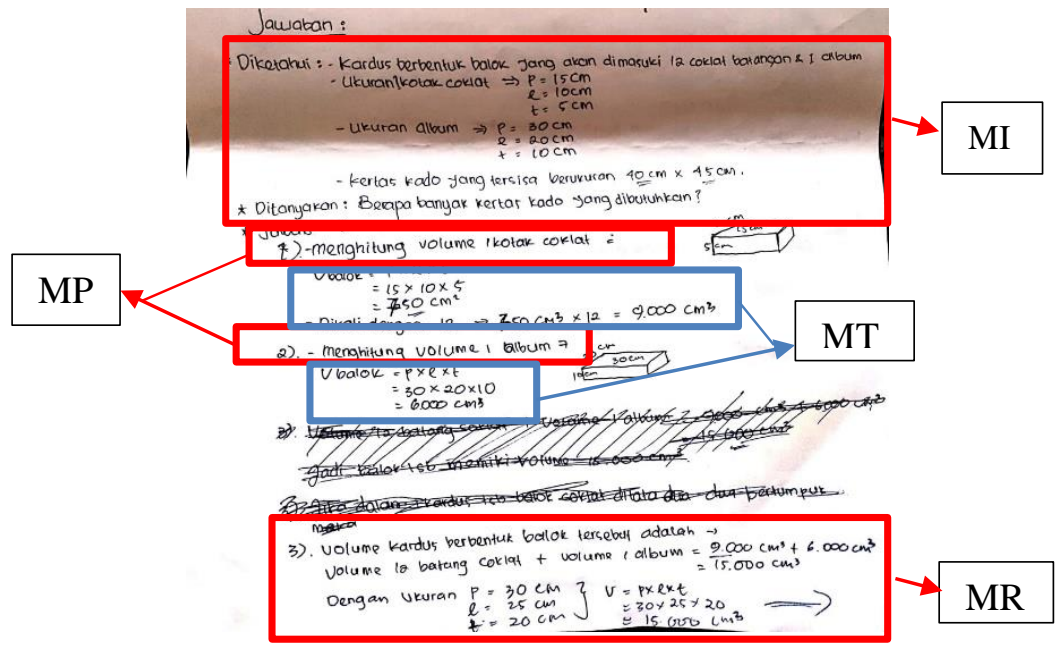

Gambar 2. Jawaban Siswa 2 (R) (i)

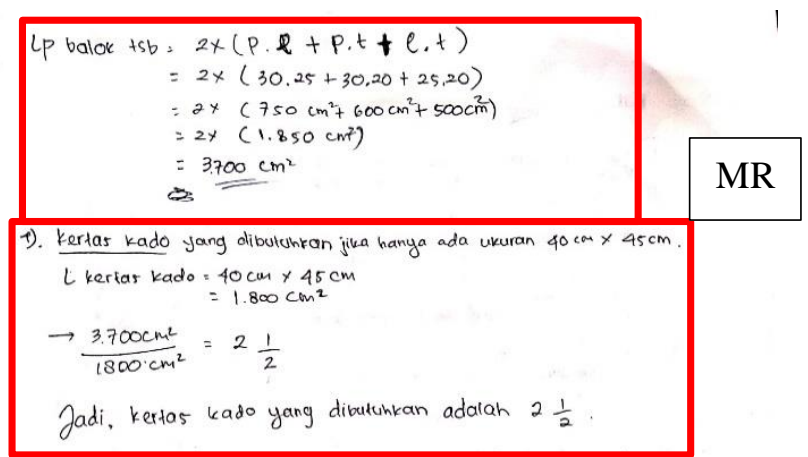

a). Rencana saya seperti diatas $\Uparrow$

a). Rencana saya seperk diatas penyelesalan dari soal tersebut seperti tio.

C). Karena jika saya membeli kertas kado itu ditoko kidak mungkin 2,5. Adan $5 a y a$ harus meoubeli 3 kerfas kado, maka jika perkiraan pengukuran cay a diatas kurang tepat sisa dari pertas kado tersebut caya buat untuk melengkapi.

Gambar 3. Jawaban Siswa 2 (R) (ii) 


\section{Mengidentifikasi Informasi}

$\mathrm{P} \quad$ : dari masalah yang ada di soal, apa informasi yang kamu dapat?

R11 : dicari banyak kertas yang ingin dibutuhkan, dan yang diketahui ukuran coklat, ukuran album dan ukuran kertas yang tersedia

$\mathrm{P} \quad$ : di situ terdapat harga coklat sebagai informasi kenapa tidak dicantumkan?

R12 : karena di sini tidak ditanyakan harga jadi informasi itu tidak saya tulis

Dari hasil pekerjaan subjek kedua pada Gambar 2 kode MI, subjek menuliskan informasi yang didapat pada soal. Hasil wawancara pada R11 siswa sudah bisa memahami informasi yang dibutuhkan. Siswa juga dapat memilah informasi yang tidak diperlukan untuk menyelesaiakan soal, berdasarkan R12. Tidak ada masalah dalam tahap ini, dikarenakan siswa sudah terbiasa menuliskan informasi sebelum mengerjakan atau menyelesaikan suatu masalah.

\section{Mengaitkan dengan pengetahuan lama}

$\mathrm{P} \quad$ : apa kamu pernah menjumpai masalah yang serupa? Atau mungkin dalam bentuk yang berbeda? seperti apa yang pernah kamu jumpai?

R21 : ada yang mirip dan pernah mengerjakan. Saya pernah melihat soal hampir sama pada materi bangun ruang namun telah diketahui ukurannya.

Dari hasil pekerjaan subjek kedua pada Gambar 2 kode MP, subjek mampu mengaitkan dengan pengetahuan lama yaitu dengan menulis pada lembar jawaban. Berdasarkan R21 siswa pernah mempelajari hal yang hampir sama dengan masalah pada materi bangun ruang.

\section{Menyebutkan teorema dan definisi terkait}

$\mathrm{P} \quad$ : bagaimana kamu menyelesaikannya?

R31 : saya menggunakan luas permukaan.

Dari hasil pekerjaan subjek kedua pada Gambar 2 kode MT, bahwa siswa sudah dapat menyebutkan teorema yang terkait yaitu dengan menuliskan rumus yang dapat ia gunakan. Pada lembar jawaban tersebut siswa menggunakan volume sesuai dengan yang pernah ia pelajari sebelumnya. Terlihat dari hasil wawancara pada A31 bahwa siswa juga menggunakan luas permukaan dalam menyelesaikan permasalahan yang ada pada soal. Tidak ada masalah pada tahap ini karena rumus yang subjek kedua gunakan sesuai dengan materi yang ada pada soal yaitu mengenai bangun ruang.

\section{Membuat rencana}

$\mathrm{P} \quad$ : sehingga apakah menurut kamu penyelesaian masalah yang pernah kamu jumpai bisa diterapkan?

R41 : iya bisa, sehingga saya menyelesaikannya dengan menghitung dulu volume dan kemudian saya cari luas permukaannya.

$\mathrm{P} \quad$ : mengapa kamu mencari luas permukaan?

R42 : karena yang akan dicari adalah banyak kertas kado yang membungkus kado, dan kertas itu menutupi permukaan kardus sehingga luas permukaan itu menurut saya cocok dalam menyelesaikan masalah ini

$\mathrm{P} \quad$ : bagaimana kamu dapat mencari luas permukaannya?

R43 : sebelumnya saya mencari ukuran balok terlebih dahulu. Dari volume tadi, saya mencari ukuran yang tepat yang jika dikalikan menghasilkan volume.

$\mathrm{P} \quad$ : setelah kamu mengetahui luas permukaan apa yang kamu lakukan

R44 : saya mencari luas kertas yang tersedia, kemudian mencari banyak kertas yang digunakan dengan cara membagi hasil dari luas permukaan dengan luas kertas dan didapat kertas yang dibutuhkan 2,5

Dari hasil pekerjaan subjek kedua pada Gambar 3 kode MR, subjek mencari volume masingmasing isi kardus lalu menjumlahkan semuanya untuk mendapatkan volume kardus. Sesuai dengan tahap sebelumnya yang menyebutkan bahwa subjek menggunakan luas permukaan, karena luas permukaan menggunakan ukuran kardus sesuai dengan R43 subjek mengalikan beberapa angka untuk mendapatkan hasil ukuran volume. Berdasarkan hasil R44 siswa membandingkan luas permukaan dan luas kertas kado. Tahap ini tidak ada kendala dikarenakan subjek sudah melakukan perencanaan yang benar sesuai dengan masalah yang terdapat pada soal. 


\section{Siswa $3(\mathbf{C})$}

Siswa dapat menuliskan informasi yang didapat dan informasi yang belum diketahui, siswa juga dapat memilah informasi yang dibutuhkan dan informasi yang tidak diperlukan. Dapat dilihat dari pekerjaan siswa Gambar 4 dan Gambar 5.

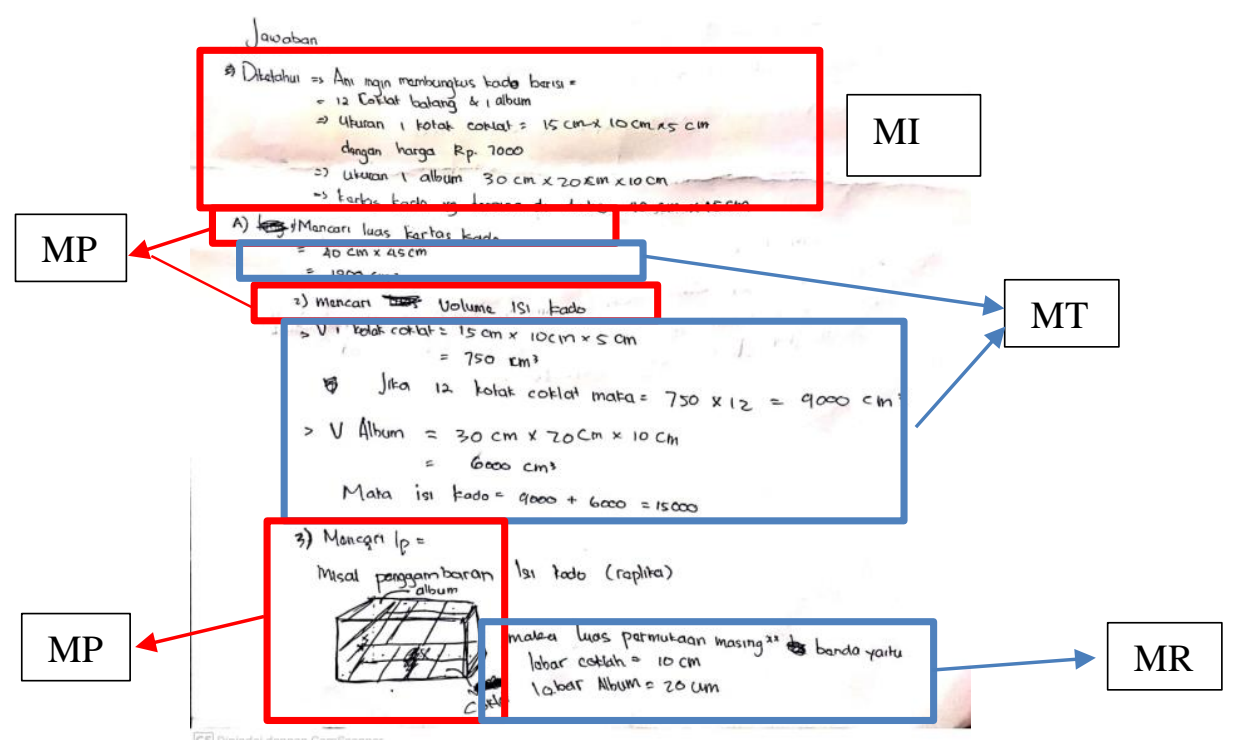

Gambar 4. Jawaban Siswa 3 (C) (i)

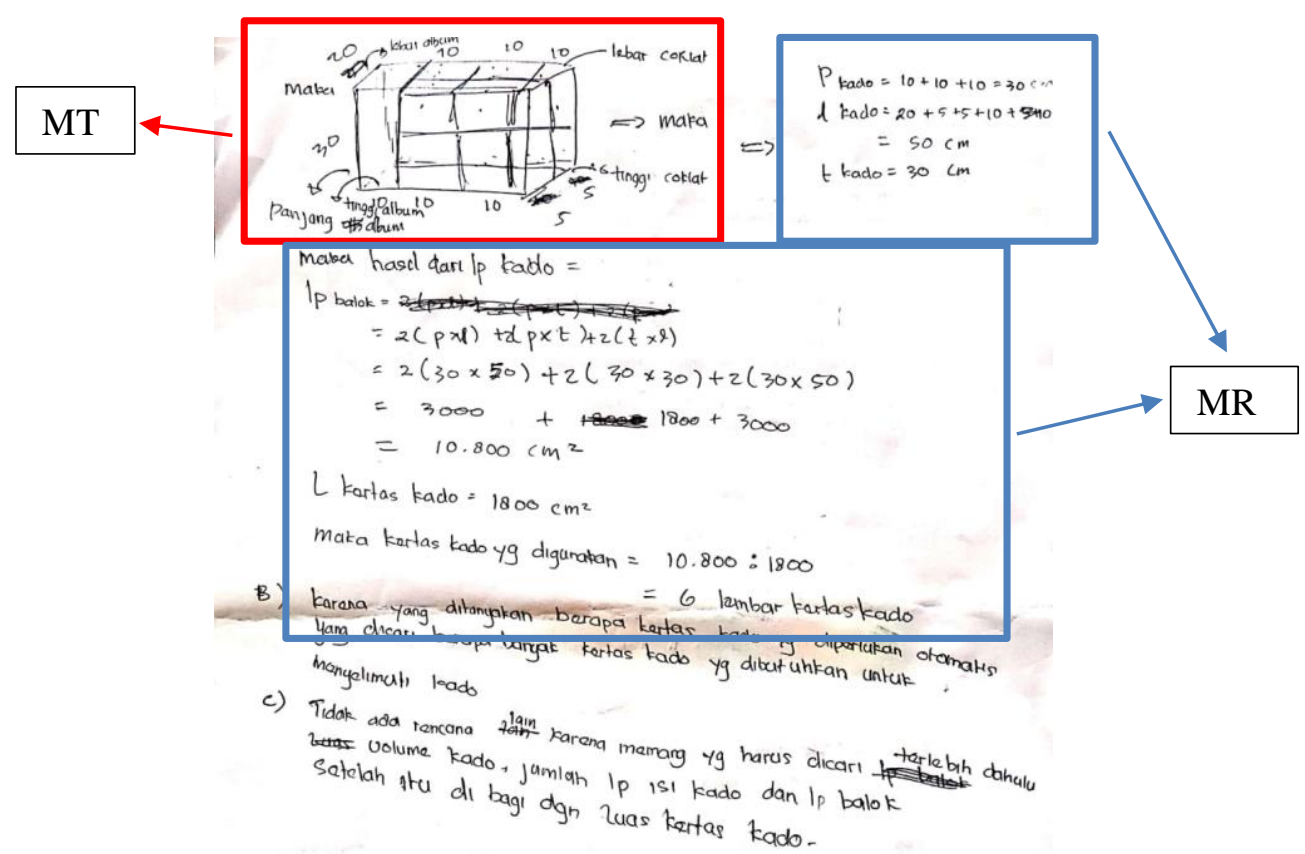

Gambar 5. Jawaban Siswa 3 (C) (ii)

\section{Mengidentifikasi Informasi}

$\mathrm{P} \quad$ : dari masalah yang ada di soal, apa informasi yang kamu dapat?

C11 : dicari banyak kertas yang ingin dibutuhkan. diketahui ukuran coklat, ukuran album dan ukuran

kertas yang tersedia

Dari hasil pekerjaan subjek ketiga pada Gambar 4 kode MI, subjek menuliskan informasi yang didapat pada soal, namun subjek tidak menuliskan informasi apa yang harus ia cari. Hasil wawancara pada C11 siswa sudah bisa memahami informasi yang dibutuhkan. Siswa juga dapat memilah informasi 
yang tidak diperlukan untuk menyelesaiakan soal. Tidak ada masalah dalam tahap ini, walaupun siswa masih kurang dalam menuliskan informasi yang ada pada soal namun siswa sudah memahami.

\section{Mengaitkan dengan pengetahuan lama}

$\mathrm{P} \quad$ : apa kamu pernah menjumpai masalah yang serupa? Atau mungkin dalam bentuk yang berbeda?

C21 : pernah, saya pernah melihatnya itu ada barang yang dimasukkan wadah, dan ditanya berapa volume.

Dari hasil pekerjaan subjek ketiga pada Gambar 4 kode MP, subjek mampu mengaitkan dengan pengetahuan lama yaitu dengan menulis pada lembar jawaban. Berdasarkan C21 siswa pernah mempelajari hal yang hampir sama dengan masalah pada materi bangun ruang.

\section{Menyebutkan teorema dan definisi terkait}

$\mathrm{P} \quad$ : jadi apa saja yang kamu gunakan untuk menyelesaikannya?

C31 : saya menggunakan rumus volume karena merupakan soal bangun ruang.

Dari hasil pekerjaan subjek ketiga pada Gambar 4 dan Gambar 5 kode MT, bahwa siswa sudah dapat menyebutkan teorema yang terkait yaitu dengan menuliskan rumus yang dapat ia gunakan. Pada lembar jawaban tersebut siswa menggunakan volume sesuai dengan yang pernah ia pelajari sebelumnya. Terlihat dari hasil wawancara pada C31 bahwa siswa juga menggunakan volume dalam menyelesaikan permasalaahan yang ada pada soal. Tidak ada masalah pada tahap ini karena rumus yang subjek kedua gunakan sesuai dengan materi yang ada pada soal yaitu mengenai bangun ruang.

\section{Membuat rencana}

$\mathrm{P} \quad$ : sehingga apakah menurut kamu penyelesaian masalah yang pernah kamu jumpai bisa diterapkan?

C41 : bisa, saya menghitung dahulu luas kertas kadonya kemudian saya menghitung volumenya

$\mathrm{P} \quad$ : bagaimana kamu menghitung volumenya?

C42 : karena kardus tidak diketahui ukurannya maka dapat dicari dari volume barang yang mengisi kardus tersebut.

$\mathrm{P} \quad$ : apakah hanya sampai disitu?

C43 : tidak setelah itu saya menggambar kardus beserta isinya untuk mengetahui ukurannya

$\mathrm{P} \quad$ : untuk apa ukuran tersebut?

C44 : untuk mencari luas permukaannya, karena kardus diselimuti kertas maka saya rasa menggunakan luas permukaan adalah cara yang tepat

$\mathrm{P} \quad$ : setelah kamu mengetahui luas permukaan apa yang kamu lakukan?

C45 : saya mencari luas kertas yang tersedia, kemudian mencari banyak kertas yang digunakan dengan cara membagi hasil dari luas permukaan dengan luas kertas dan didapat kertas yang dibutuhkan 6 kertas

P : lalu untuk apa volume yang kamu cari diawal tadi?

C46 : saya bingung tadi untuk mengetahui ukuran baloknya jadi volume tadi tidak saya gunakan

Dari hasil pekerjaan subjek ketiga pada Gambar 4 dan Gambar 5 kode MR, subjek merencanakan mencari volume masing-masing isi kardus lalu menjumlahkan semuanya untuk mendapatkan volume kardus. Sesuai dengan C41 dan C42 siswa akan mencari ukuran kardus untuk digunakan mencari luas permukaan. Terlihat pada C43 siswa mulai menggambar pola untuk menemukan ukuran kardus, dikarenakan siswa merasa kebingungan ketika hanya diketahui volume. Berdasarkan C45 dengan menggunakan pola gambar siswa dapat menyelesaikan permasalahan, karena ukuran kardus dapat diketahui dan siswa dapat mencari luas permukaan yang kemudian dibagi dengan luas kertas. Pada tahap ini siswa sempat mengalami kendala akan tetapi hal tersebut dapat diatasi dan siswa menemukan cara lain untuk menyelesaikan permasalahan

Berdasarkan hasil dari penelitian ketiga subjek didapatkan bahwa semua subjek sudah bisa memahami dan mengidentifikasikan mana informasi yang digunakan dan mana informasi yang tidak dibutuhkan. Hal ini sejalan dengan hasil penelitian Yuwono, Supanggih, \& Ferdiani (2018) yang menyatakan bahwa kebanyakan siswa tidak menuliskan tahap perencanaan namun siswa sudah bisa memahami apa yang dimaksud soal. Dalam penelitian yang dilakukan oleh Kang (2015) masih ditemukan siswa yang menuliskan informasi yang tidak penting dalam proses pemecahan masalah, 
namun dalam penelitian ini ketiga siswa sudah dapat mengidentifikasi informasi yang diperlukan sehingga informasi yang berlebih tidak ikut dituliskan dalam tahap perencanaan.

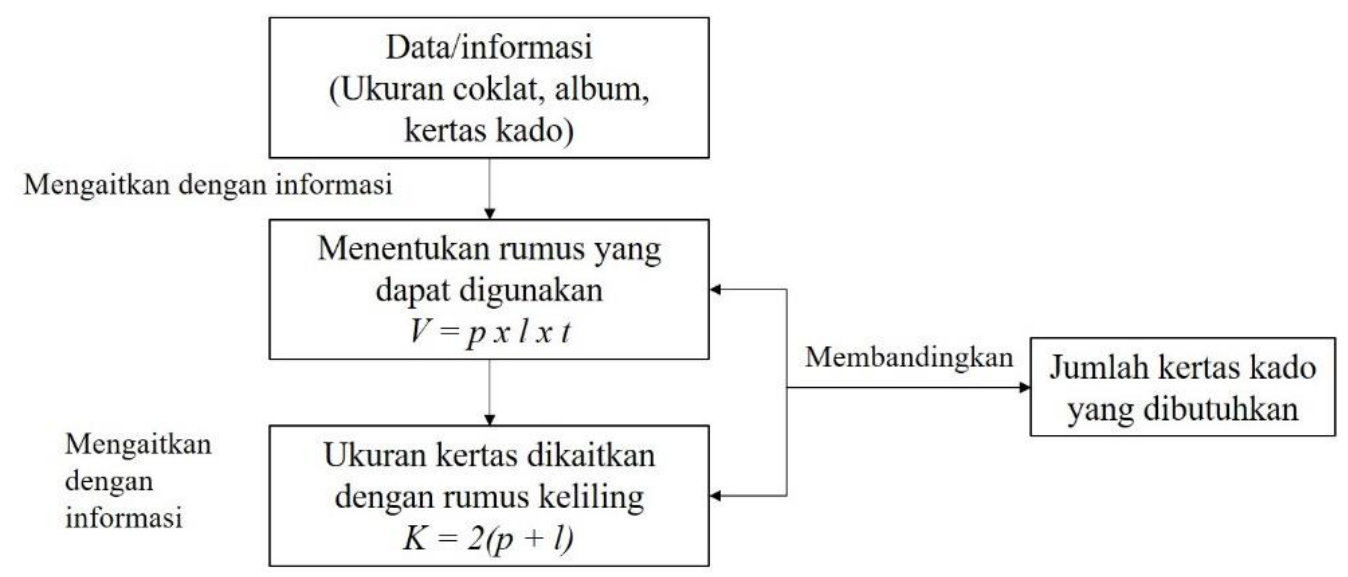

Gambar 6. Diagram Alir Pemikiran Siswa 1 (A)

Pada Gambar 6 terlihat mengenai diagram alir penyelesaian masalah siswa 1 (A). Dalam merencanakan penyelesaian, siswa 1 menggunakan rumus volume, namun ketika mengaitkan dengan konteks kehidupan nyata siswa keliru memilih konsep. Konsep yang digunakan merupakan konsep 2 dimensi. Hal ini sesuai dengan penelitian Arumanita, Susanto, \& Rahardi (2018) yang menyatakan bahwa pada tahap pemecahan masalah salah satu kesulitannya yaitu mentransfer pengetahuan yang telah dimiliki dalam pengerjaan masalah yang sedang dihadapi, sehingga siswa seringkali keliru dalam memilih konsep yang harus digunakan.

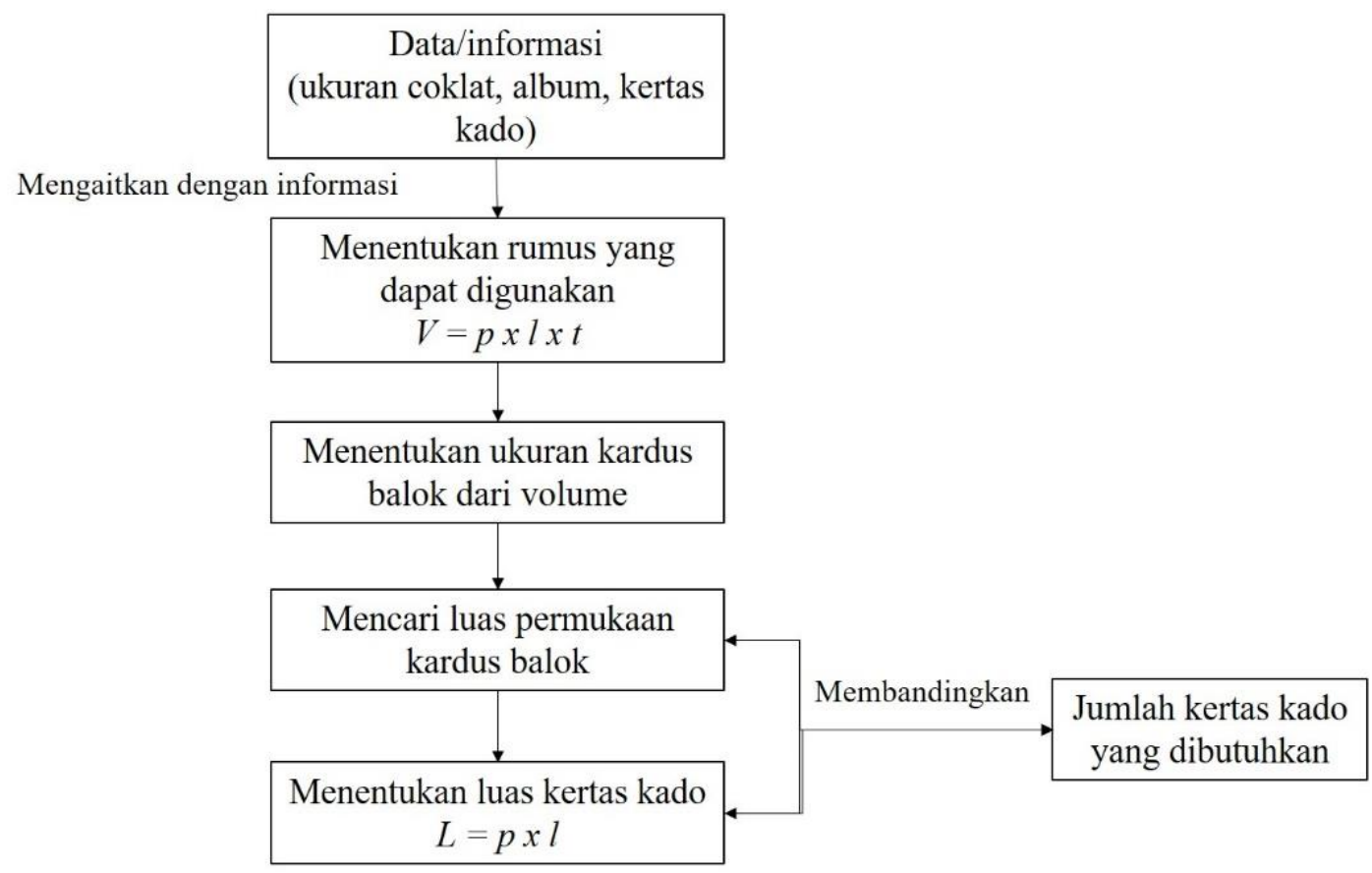

Gambar 7. Diagram Alir Pemikiran Siswa 2 (R)

Pada Gambar 7 tampak bahwa siswa 2 (R) menerapkan rumus/konsep yang telah ia pelajari, yaitu volume balok. Selain itu siswa kedua juga menggunakan sedikit perkiraan untuk mendapatkan hasil yang diinginkan. Hal ini sejalan dengan penelitian yang dilakukan oleh Widyastuti \& Pujiastuti (2014) bahwa pembelajaran yang menggunakan konteks nyata memiliki dampak yang positif terhadap pemahaman konsep dan kemampuan berpikir siswa. Namun siswa kedua melakukan kesalahan ketika permasalahan menggunakan konteks nyata. Siswa kedua tidak mengecek ulang ukuran kardus yang didapat. 


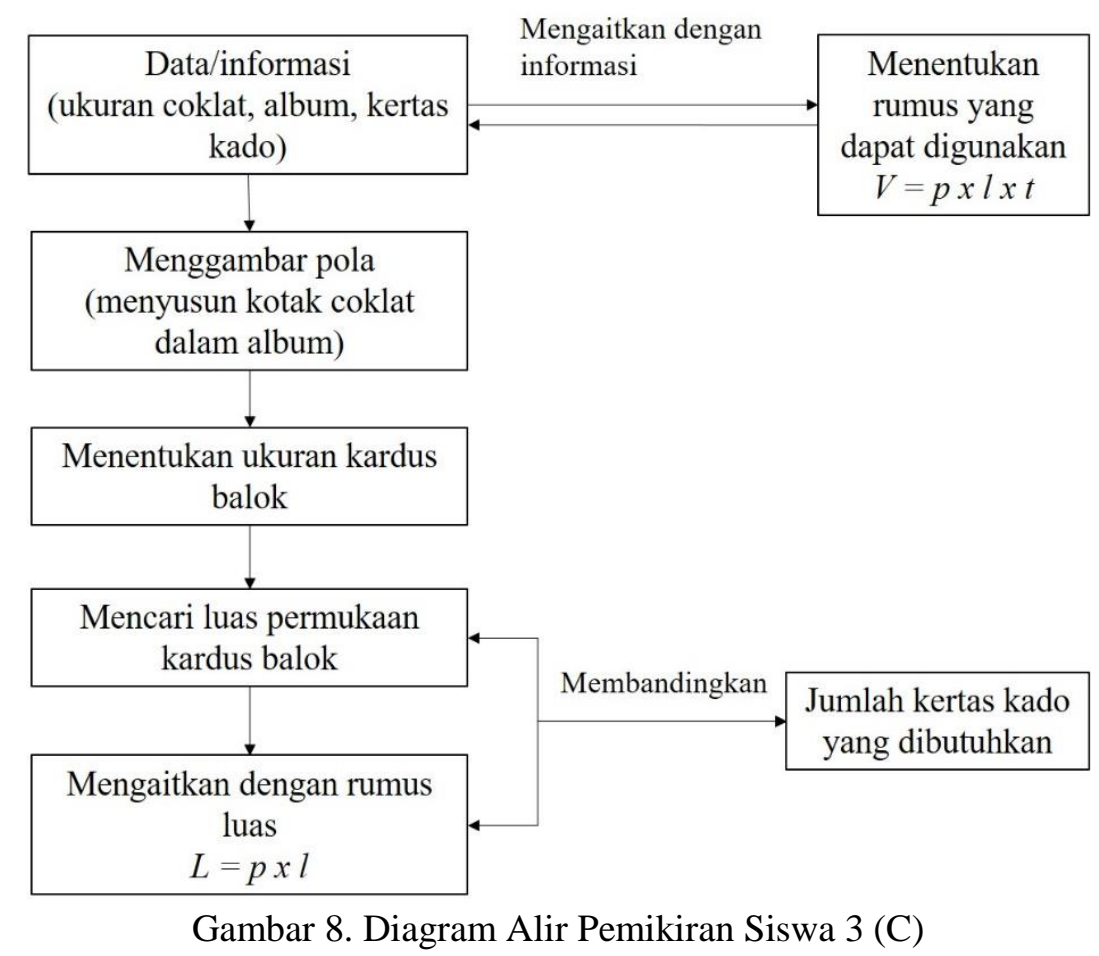

Pada Gambar 8 tampak alur pemikiran siswa 3 (C) dalam menyelesaikan permasalahan. Siswa 3 pada mulanya mencoba menggunakan rumus yang telah ia peroleh sebelumnya yaitu volume balok. Akan tetapi, ia tidak dapat menemukan berapa ukuran kardus yang dibutuhkan. Kemudian, siswa melakukan perencanaan lain yaitu dengan menggambar sketsa untuk menentukan ukuran kardus. Perencanaan lain yang dilakukan siswa ketiga menunjukkan bahwa siswa sudah dapat mengaitkan permasalahan dengan bantuan konteks nyata. Hal ini didukung dengan penelitian yang telah dilakukan Hartono \& Karnasih (2017) bahwa pembelajaran dengan pemodelan matematika sangat penting untuk melatih kreatifitas siswa dalam menyelesaikan soal yang berkaitan dengan kehidupan nyata.

Hasil pekerjaan siswa pertama dan siswa kedua menunjukkan bahwa siswa yang merasa kesulitan saat menjumpai soal dengan materi bangun ruang khususnya balok. Berdasarkan penelitian Muchyidin, Nurlatif, \& Nursuprianah (2020), penyebab miskonsepsi pada materi luas permukaan yaitu siswa menganggap konsep kurang penting sehingga siswa lebih suka untuk menghafal konsep. Kebiasaan ini menyebabkan siswa tidak mampu mengaitkan suatu konsep dengan konsep lainnya. Pada penelitian ini diperoleh bahwa dua dari tiga subjek cenderung hanya menggunakan rumus tanpa memperhatikan konteks.

\section{SIMPULAN}

Berdasarkan hasil penelitian diperoleh bahwa dua dari tiga subjek cenderung menggunakan konsep/rumus saja tanpa memperhatikan konteks nyata. Sedangkan subjek ketiga pada mulanya juga menggunakan rumus akan tetapi ditengah perencanaan penyelesaian ia mengaitkan dengan konteks nyata yaitu dengan cara menggambar sketsa untuk mendapatkan ukuran yang sesuai. Hal ini dikarenakan kurangnya pengenalan konteks pada siswa.

\section{DAFTAR PUSTAKA}

Anggo, M. (2011). Pemecahan Masalah Matematika Kontekstual untuk Meningkatkan Kemampuan Metakognisi Siswa. Edumatika, 1(2), 35-42.

Arfiana, A., \& Wijaya, A. (2018). Problem Solving Skill of Students of Senior High Schools and Islamic High Schools in Tegal Regency in Solving the Problem of PISA based on Polya's Stage. Jurnal Riset Pendidikan Matematika, 5(2), 211-222. https://doi.org/10.21831/jrpm.v5i2.15783 
Arumanita, D. M., Susanto, H., \& Rahardi, R. (2018). Kemampuan Pemecahan Masalah Siswa SMP Negeri 1 Papar pada Materi Bangun Ruang. Jurnal Math Educator Nusantara: Wahana Publikasi Karya Tulis Ilmiah Di Bidang Pendidikan Matematika, 4(2), 104. https://doi.org/10.29407/jmen.v4i2.12106

Dindyal, J., Tay, E. G., Toh, T. L., Leong, Y. H., \& Quek, K. S. (2012). Mathematical Problem Solving for Everyone: A New Beginning. The Mathematics Educator, 13(2), 1-20.

Hartono, J. A., \& Karnasih, I. (2017). Pentingnya Pemodelan Matematis dalam Pembelajaran Matematika. Semnastika Unimed, 1-8.

Kaliky, S. H., Nurlaelah, E., \& Jupri, A. (2019). Analysis of Mathematical Problem Solving Ability Students of Junior High School to Polya Model. Journal of Physics: Conference Series, 1157(4), 042064. https://doi.org/10.1088/1742-6596/1157/4/042064

Kang, W. (2015). Implications from Polya and Krutetskii. In Selected Regular Lectures from the 12th International Congress on Mathematical Education (pp. 405-416). Cham: Springer International Publishing. https://doi.org/10.1007/978-3-319-17187-6_23

Lestari, R. S., Rohaeti, E. E., \& Purwasih, R. (2018). Profil Kemampuan Koneksi Matematis Siswa SMP dalam Menyelesaikan Soal Bangun Ruang Sisi Datar Ditinjau dari Kemampuan Dasar. JIPMat, 3(1), 51-58. https://doi.org/10.26877/jipmat.v3i1.2220

Muchyidin, A., Nurlatif, L., \& Nursuprianah, I. (2020). Miskonsepsi Siswa pada Pemahaman Konsep Bangun Ruang. JRPM (Jurnal Review Pembelajaran Matematika), 5(2), 72-86. https://doi.org/10.15642/jrpm.2020.5.2.72-86

Nadhifa, N., Maimunah, M., \& Roza, Y. (2019). Analisis Kemampuan Pemecahan Masalah Siswa pada Materi Bangun Ruang Sisi Datar. NUMERICAL: Jurnal Matematika Dan Pendidikan Matematika, 3(1), 63-76. https://doi.org/10.25217/numerical.v3i1.477

Polya, G. (1945). How to solve it. Humphrey Milford: Princeton University Press.

Puadi, E. F. W. (2017). Analisis Peningkatan Kemampuan Koneksi Matematis Mahasiswa Ptik Melalui Pembelajaran Berbasis Masalah. JUMLAHKU: Jurnal Matematika Ilmiah STKIP Muhammadiyah Kuningan, 2(1), 85-103. Retrieved from http://jurnal.upmk.ac.id/index.php/jumlahku/article/view/139

Putra, H. D., Thahiram, N. F., Ganiati, M., \& Nuryana, D. (2018). Kemampuan Pemecahan Masalah Matematis Siswa SMP pada Materi Bangun Ruang. JIPM (Jurnal Ilmiah Pendidikan Matematika), $6(2), 82-90$.

Rio, M., \& Pujiastuti, H. (2020). Analisis Kemampuan Pemecahan Masalah Matematik Siswa SMP pada Materi Bilangan Bulat. AKSIOMA : Jurnal Matematika Dan Pendidikan Matematika, 11(1), 7081. https://doi.org/10.26877/aks.v11i1.6105

Rofi' ah, N., Ansori, H., \& Mawaddah, S. (2019). Analisis Kesalahan Siswa dalam Menyelesaikan Soal Cerita Matematika berdasarkan Langkah Penyelesaian Polya. EDU-MAT: Jurnal Pendidikan Matematika, 7(2), 120. https://doi.org/10.20527/edumat.v7i2.7379

Saputri, R. A. (2019). Analisis Pemecahan Masalah Soal Cerita Materi Perbandingan Ditinjau dari Aspek Merencanakan Polya. Wacana Akademika: Majalah Ilmiah Kependidikan, 3(1), 21-38.

Simpol, N. S. H., Shahrill, M., Li, H.-C., \& Prahmana, R. C. I. (2017). Implementing Thinking Aloud Pair and Pólya Problem Solving Strategies in Fractions. Journal of Physics: Conference Series, 943(1), 012013. https://doi.org/10.1088/1742-6596/943/1/012013 
Utami, R. (2013). Model Pembelajaran Berbasis Masalah dengan Langkah Penyelesaian berdasarkan Polya dan Krulik-Rudnick Ditinjau dari Kreativitas Siswa. Jurnal Ilmiah Pendidikan Matematika, $1(1), 82-98$.

Widyastuti, N. S., \& Pujiastuti, P. (2014). Pengaruh Pendidikan Matematika Realistik Indonesia (PMRI) terhadap Pemahaman Konsep dan Berpikir Logis Siswa. Jurnal Prima Edukasia, 2(2), 183. https://doi.org/10.21831/jpe.v2i2.2718

Yuwono, T., Supanggih, M., \& Ferdiani, R. D. (2018). Analisis Kemampuan Pemecahan Masalah Matematika dalam Menyelesaikan Soal Cerita Berdasarkan Prosedur Polya. Jurnal Tadris Matematika, 1(2), 137-144. https://doi.org/10.21274/jtm.2018.1.2.137-144 